\title{
Online Appendix \\ There Is No Free House: Ethnic Patronage in a Kenyan Slum
}

\author{
Benjamin Marx \\ Thomas M Stoker
}

Tavneet Suri

December 2018 


\section{Appendix 1: Attrition}

The survey we conducted on the phone (see section III.A) had some attrition. In addition, we are missing controls for hedonic variables collected in the survey of community elders (see section III.B). Here, we provide two checks on attrition, both of which illustrate that attrition does not seem to play an important role.

The attrition in our survey comes from the residents that could not be reached by phone and those that did not have phones. In particular, of the residents that could not be reached by phone, we sampled $20 \%$ and focused on finding this subset of residents in the field to complete the survey. We were able to locate $80 \%$ of target respondents in this subsample. In addition, of the residents without phone numbers, we sampled $14 \%$ to conduct field surveys and were able to find $77 \%$ of these. As shown in Appendix Figure A1, the total target sample size was 18,797 residents, and the number of residents we reached was 18,254, giving us an unweighted attrition rate of $3 \%$ and a weighted attrition rate of $11 \%$ (sampling weights are used throughout all of our analysis) ${ }^{1}$

These attrition rates are obviously not negligible, although they are not strikingly high for urban areas (for example, Jack and Suri (2014) find higher attrition rates in Nairobi). The context of Kibera makes tracking residents harder for a number of reasons. First, we conducted our surveys during weekends, but not in the evenings because of safety concerns for our staff. Individuals living in the slum are often out looking for work or travelling long distances for work and therefore not easily available during the day, including on weekends. Second, even though our surveys were conducted shortly (6 months) after the initial listing exercise, there are reasonably high mortality rates in Kibera which arguably made it more difficult to locate our entire target sample. In our survey data, $4 \%$ of respondents reported that at least one member of their household died in the past 6 months.

However, since this does not explain all the attrition in the sample, we present two checks to show that attrition is not driving our results, which we report in Table A1. The first check is a specification where we drop the higher attrition EAs. We keep the EAs that have attrition rates of $5 \%$ or less. Results for our two main specifications are reported in columns (1) and (2) of Table A1. As can be seen, our results are robust to dropping the higher attrition EAs. The second check we conduct is to weight the regressions as proposed by Fitzgerald, Gottschalk and Moffitt (1998). Once again, our results are mostly robust to this re-weighting as seen in columns (5) and (6).

In addition to attrition from the phone survey, we are missing hedonic variables (housing characteristics and amenities) in two zones where community elders refused to be interviewed. In Table A1, we also show that our main results on rental prices are robust to this particular type of attrition. We conduct the same checks as above: in columns (3)-(4), we show that our results are robust to estimation on a subsample with low attrition (where we only keep EAs with attrition rates under

\footnotetext{
${ }^{1}$ By definition of our sampling strategy, attrition was null in the subsample of households that we surveyed by phone. Attrition is therefore highest in the subset of households without phone, and the subset of households who could not be reached on their phones, which also have the largest sampling weights by way of the sampling strategy.
} 
$5 \%$. In columns (7)-(8) we use the same weighting procedure from Fitzgerald, Gottschalk and Moffitt (1998). Though we lose statistical significance on the LC match in column (7), our point estimates for the two variables of interest (LC and TC matches) remain unchanged throughout.

\section{Appendix 2: Geospatial Methods and Satellite Imagery Analysis}

\section{A2.1. Data collection}

Our initial listing exercise in Kibera involved collecting GPS coordinates for every household in our sample. Coordinates were received and recorded at the center of each dwelling using Garmin GPS receivers, which are usually accurate within 15 meters or less (http:/ / www 8 .garmin.com/ about GP S /). Households whose coordinates could not be placed within Kibera after data cleaning were dropped from our sample. To improve the geo-positioning of our satellite pictures, we also collected GPS coordinates for all major installations in Kibera (schools, churches, etc.) and major arteries and boundaries, including the railway that cuts through the slum through a West-East axis.

\section{A2.2. Mapping of Kibera}

After the end of the first wave of listing, we used various sources of information to create our own map of the Kibera area, including location, sublocation, village and enumeration area boundaries. The villages are the finest level of governance we could map with accuracy (some villages are divided into zones, but our data does not allow us to precisely demarcate these zones). Kibera is divided into 17 villages, which are not administrative entities but whose boundaries are wellknown by residents of the slum. To construct the map of villages, we used the information reported by households (who were asked to name their village and zone in the listing exercise), a land use shapefile made publicly available by the Center for Sustainable Urban Development (CSUD) at Columbia University, various maps created by the Map Kibera project (http://mapkibera. org/), our GPS coordinates of major installations in Kibera, and our own satellite pictures of the area which helped us determine relevant boundaries when those are marked by a street or a river. The Enumeration Area boundaries (drawn as part of the 2009 Population Census) were manually digitized from maps given to us in paper format by the Kenyan National Bureau of Statistics.

\section{A2.3. Empirical validation of the luminosity methodology}

We now provide evidence that the data from our satellite images are indeed correlated with a range of socioeconomic outcomes and housing characteristics, using data from the 2009 census. Since EAs are the geographical unit of reference in the KNBS census, all the luminosity data available at a 0.5 meters resolution is aggregated to the level of the EA for this empirical validation. Throughout 
all specifications, we use the sample of only informal EAs (576 out of 643 EAs), we weight the regression by the size of the EA, and we control for sublocation fixed effects.

Our first specification looks at the correlation between luminosity and a variety of individual level demographic, education and occupation characteristics. The regression is as follows:

$$
L_{i j}=\alpha+\beta_{w} W P_{i j}+\beta_{b} B_{i j}+\beta_{s} S e c_{i j}+\beta_{u} U n i v_{i j}+\beta_{a} A g e_{i j}+\eta_{j}+\epsilon_{i j}
$$

where $L_{i j}$ is the mean luminosity reflected by EA $i$ in sublocation $j, W P_{i j}$ is the average fraction of household members working for pay in the EA, $B_{i j}$ is the average fraction of household members running a business, $S e c_{i j}$ is the fraction of household heads that have some secondary education, $U n i v_{i j}$ is the fraction of household heads that have some university education, $A_{g} e_{i j}$ is the average age of the household head, $\eta_{j}$ is a set of sublocation fixed effects, and the coefficients of interest are the five $\beta$ coefficients.

We report the results of this specification in the first column of Appendix Table A2. We find that higher luminosity is associated with higher secondary education and (not significantly) with higher university education. It is also correlated with the fraction of household heads that run a business and with the fraction who report having some form of paid employment.

We then report on a specification that includes a number of standard wealth measures: ${ }^{2}$

$$
L_{i j}=\alpha+\beta_{m} W M_{i j}+\beta_{f} F_{i j}+\beta_{c} C_{i j}+\beta_{a} W A_{i j}+\beta_{e} E_{i j}+\eta_{j}+\epsilon_{i j}
$$

where $W M_{i j}$ is the fraction of households in the EA with walls made of mud mixed with cement, $F_{i j}$ is the fraction of households with cement floors, $C_{i j}$ is the fraction of households whose main cooking fuel is charcoal, $W A_{i j}$ is the fraction of households whose main water source is a water vendor, and $E_{i j}$ is the fraction of households whose main light source is electricity.

Appendix Table A2, column (2) reports the results from this specification. Luminosity correlates significantly and positively with the floor being made of cement (the highest-quality floor material) and with the main source of drinking water being a water vendor $3^{3}$ Luminosity is also significantly negatively associated with a mix of mud and cement being used as the material to construct their walls and with charcoal being used as cooking fuel - two indicators of relative deprivation within the slum. The coefficient on access to electricity is insignificant and negative - possibly because segments of the slum are illegally connected to the city electricity grid.

Finally, we look at correlations of luminosity with measures of household expenditures and poverty. The census does not collect these measures, instead we estimate them using the poverty mapping methods described in Elbers et al. (2003) and data from Jack and Suri (2014). We look at household expenditures and two different measures of poverty: the fraction of households in

\footnotetext{
${ }^{2}$ These measures are those used in the poverty mapping literature (Elbers et al. (2003)) and in Demographic and Health Surveys (DHS) conducted across the developing world.

${ }^{3}$ These households typically pay for clean water, as opposed to using poorer quality sources such as public pumps.
} 
the EA that live on less than \$1.25 (PPP) a day and the fraction that live on less than \$2 (PPP) a day. Since these are generated regressors, we report bootstrap standard errors. In addition, we look at correlations of luminosity with retailer presence and road access in the EA. Since these five variables are highly correlated with each other, column (3) reports coefficients from separate regressions of each of these variables on luminosity, using the following specification:

$$
L_{i j}=\alpha+\beta_{x} X_{i j}+\eta_{j}+\epsilon_{i j}
$$

where $X_{i j}$ is one of the economic variables of interest, i.e. one of the following: (i) the fraction of households living on less than $\$ 1.25 /$ capita/day; (ii) the fraction of households living on less than \$2/capita/day; (iii) average per capita consumption in the EA; (iv) whether there is a retail business in the EA; and (v) the fraction of the area of the EA that is within 15 meters of a road.

We find that the EA luminosity correlates positively with estimated household expenditures and negatively with the two poverty measures. Appendix Figure A3 presents a visual analysis of these results, comparing average luminosity and average consumption across EAs. To further support these results, we find that EAs with higher luminosity are more likely to have a retail business and are likely to be closer to roads.

\section{Appendix 3: The Role of Diversity and Unemployment}

\section{A3.1: Youth Gangs and Unemployment}

While there is virtually no police presence in most areas of the slum, Kibera is host to a number of youth gangs which participate in organized banditry and are notorious for their frequent robberies, violent crimes, and other forms of intimidation. The gangs active in Kibera are affiliated with larger groups operating nationally, such as the Mungiki who claim ties to the anti-colonial Mau Mau movement, and the Kamkunji, also known as the Taliban. Kiberas youth constitute a primary recruitment target for these groups, since all Kenyan gangs tend to recruit amongst unemployed and disenfranchised youth in poor urban areas (International Crisis Group 2013). Like elsewhere in Kenya, gang membership in Kibera is typically ethnic-based - for example, Kikuyu for the Mungiki and Luo for the Kamkunji. The gangs control and levy taxes over certain public goods and amenities (water, sanitation, electricity, transport), and they may provide protection to co-ethnic individuals in cases of interethnic disputes. Joireman and Vanderpoel (2011) document the role of the Kamkunji gang, which claims to defend Luo interests in Kibera and systematically intervenes in favor of Luo tenants in cases of housing-related disputes. The group convenes once a week in a formal meeting where Luo residents are invited to express their grievances and report on disputes with their landlords. The Kamkunji are so influential in some areas of the slum that they may entirely substitute for the authority of the chief, particularly in Gatwekera village (a village where we had some difficulty interviewing community elders and chiefs, as we describe below). 


\section{A3.2: Heterogeneity Results}

Appendix Table A5 reports some heterogeneity results which suggest that local ethnic diversity and gang presence hamper the rent extraction organized by chiefs and landlords. We use youth unemployment in the EA as a proxy for the local presence of youth gangs, since unemployed youth constitute the primary source of recruits for these gangs. We use a dummy for the EA-level youth unemployment rate being above the median. In columns (1) and (2) of this table, we find that high unemployment partially offsets the effects of the landlord-chief tribe match: tenants in this case no longer pay higher rents. The coefficient on the interaction with the tenant-chief tribe match is also negative, but small and not significant. This provides suggestive evidence that rent extraction by chiefs and landlords is hampered when local gangs are active in the area (anecdotal evidence also suggests that gangs intervene to protect co-ethnic tenants).

In columns (3)-(5), we look at heterogeneous treatment effects with local ethnic diversity measured at the EA, zone, or village level. Ethnic diversity is computed using a Herfindahl index of the form: $H=1-\sum_{i=1}^{N} s_{i}^{2}$, where $s_{i}$ is the fraction of the area (EA, zone, or village) population belonging to tribe $i$ (a high index here stands for high ethnic diversity). The variable we use for the relevant interaction is a dummy for the diversity variable being greater than the median value in the sample. We find that residents with a LC match pay $12 \%$ to $17 \%$ lower rents in relatively more diverse areas.

Throughout this table we control for the interaction of the tribe match variables with the average level of education of the household head, the average wealth in the EA and the poverty rate in the EA, since diversity and unemployment may correlate with other socio-economic characteristics. For wealth, we use a principal components analysis for the asset and economic variables from the 2009 census to create a wealth index. For poverty, we use the poverty mapping methodology in Elbers, Lanjouw and Lanjouw (2003) and data from Jack and Suri (2014) to create EA level poverty rates, i.e. the fraction of households in the EA that live on less than $\$ 2$ a day. 
Appendix Table A1: Attrition Checks

Dependent Variable is Log Rent

\begin{tabular}{|c|c|c|c|c|c|c|c|c|}
\hline & \multicolumn{4}{|c|}{ Low Attrition Samples } & \multicolumn{4}{|c|}{ Attrition Weights } \\
\hline & $\begin{array}{c}\text { (1) } \\
\text { Phone }\end{array}$ & $\begin{array}{c}\text { (2) } \\
\text { Phone }\end{array}$ & $\begin{array}{c}\text { (3) } \\
\text { Controls }\end{array}$ & $\begin{array}{c}(4) \\
\text { Controls }\end{array}$ & $\begin{array}{c}\text { (5) } \\
\text { Phone }\end{array}$ & $\begin{array}{c}(6) \\
\text { Phone }\end{array}$ & $\begin{array}{c}(7) \\
\text { Controls }\end{array}$ & $\begin{array}{c}(8) \\
\text { Controls }\end{array}$ \\
\hline Landlord-Chief (LC) tribe match & $\begin{array}{c}0.093^{* * *} \\
{[0.022]}\end{array}$ & $\begin{array}{c}0.094^{* * *} \\
{[0.020]}\end{array}$ & $\begin{array}{l}0.076^{* *} \\
{[0.030]}\end{array}$ & $\begin{array}{c}0.104^{* * *} \\
{[0.028]}\end{array}$ & $\begin{array}{l}0.068^{* *} \\
{[0.028]}\end{array}$ & $\begin{array}{c}0.081^{* * *} \\
{[0.027]}\end{array}$ & $\begin{array}{c}0.092 \\
{[0.070]}\end{array}$ & $\begin{array}{l}0.152^{* *} \\
{[0.065]}\end{array}$ \\
\hline Tenant-Chief (TC) tribe match & $\begin{array}{c}-0.074^{* * *} \\
{[0.027]}\end{array}$ & $\begin{array}{c}-0.073^{* * *} \\
{[0.025]}\end{array}$ & $\begin{array}{c}-0.074^{* * *} \\
{[0.028]}\end{array}$ & $\begin{array}{c}-0.049^{* *} \\
{[0.023]}\end{array}$ & $\begin{array}{c}-0.071^{* * *} \\
{[0.026]}\end{array}$ & $\begin{array}{c}-0.060^{* *} \\
{[0.023]}\end{array}$ & $\begin{array}{c}-0.208^{* * *} \\
{[0.064]}\end{array}$ & $\begin{array}{c}-0.167^{* *} \\
{[0.068]}\end{array}$ \\
\hline Landlord-Tenant (LT) tribe match & $\begin{array}{c}-0.010 \\
{[0.019]}\end{array}$ & $\begin{array}{c}-0.009 \\
{[0.021]}\end{array}$ & $\begin{array}{c}0.006 \\
{[0.022]}\end{array}$ & $\begin{array}{c}0.020 \\
{[0.022]}\end{array}$ & $\begin{array}{c}0.007 \\
{[0.019]}\end{array}$ & $\begin{array}{c}0.013 \\
{[0.020]}\end{array}$ & $\begin{array}{c}0.014 \\
{[0.058]}\end{array}$ & $\begin{array}{c}0.035 \\
{[0.061]}\end{array}$ \\
\hline All tribes match (ALL) & & $\begin{array}{c}-0.004 \\
{[0.056]}\end{array}$ & & $\begin{array}{c}-0.098 \\
{[0.062]}\end{array}$ & & $\begin{array}{c}-0.044 \\
{[0.061]}\end{array}$ & & $\begin{array}{c}-0.202 \\
{[0.141]}\end{array}$ \\
\hline Dependent Variable Mean & 7.267 & 7.267 & 7.289 & 7.289 & 7.254 & 7.254 & 7.264 & 7.264 \\
\hline All Controls & $x$ & $x$ & $x$ & $x$ & $x$ & $X$ & $x$ & $x$ \\
\hline R-squared & .431 & .431 & .301 & .302 & .428 & .428 & .643 & .644 \\
\hline Observations & 11233 & 11233 & 10361 & 10361 & 14178 & 14178 & 12622 & 12622 \\
\hline
\end{tabular}

Note: Standard errors clustered at the location-household tribe-landlord tribe level (reported in brackets). ${ }^{*} \mathrm{p}<0.1,{ }^{* *} \mathrm{p}<0.05,{ }^{* * *} \mathrm{p}<0.01$.

Columns (1)-(2) and (5)-(6) look at attrition from the resident survey conducted on the phone.

Columns (3)-(4) and (7)-(8) look at missing controls for hedonic variables (housing characteristics and amenities)

Low attrition sample covers the EAs with a $5 \%$ attrition rate or less.

The attrition weights are computed using the methods in Fitzgerald, Gottschalk and Moffitt (1998).

All controls refers to village fixed effects, resident demographics, and EA-level controls (see text for details). 


\section{Appendix Table A2: Correlations of Luminosity with Wealth, Consumption and Poverty}

\begin{tabular}{|c|c|c|c|c|c|}
\hline Relationship with Demographics & & Relationship with Wealth & & Relationship with Other Indicators & \\
\hline Fraction of $\mathrm{HH}$ members working & $\begin{array}{l}14.782^{*} \\
{[7.840]}\end{array}$ & Walls are made of mud or cement & $\begin{array}{c}-5.955^{* *} \\
{[2.507]}\end{array}$ & Poverty ( $\$ 1.25$ per day) & $\begin{array}{c}-51.992^{* * *} \\
{[18.497]}\end{array}$ \\
\hline Fraction of $\mathrm{HH}$ members in business & $\begin{array}{c}38.907^{* * *} \\
{[10.341]}\end{array}$ & Floor is made of cement & $\begin{array}{c}16.963^{* * *} \\
{[3.581]}\end{array}$ & Poverty ( $\$ 2$ per day) & $\begin{array}{c}-39.862^{* * *} \\
{[11.938]}\end{array}$ \\
\hline HH head has some secondary educ & $\begin{array}{c}17.584^{* *} \\
{[8.218]}\end{array}$ & Main cooking fueld is charcoal & $\begin{array}{c}-9.690^{* *} \\
{[4.061]}\end{array}$ & Log consumption per capita & $\begin{array}{c}24.503^{* * *} \\
{[6.554]}\end{array}$ \\
\hline HH head has some univ educ & $\begin{array}{c}21.124 \\
{[13.993]}\end{array}$ & Main water source is vendor & $\begin{array}{c}5.863^{* * *} \\
{[1.943]}\end{array}$ & $\%$ of EA within $15 \mathrm{~m}$ of road & $\begin{array}{l}8.360^{* * *} \\
{[2.861]}\end{array}$ \\
\hline Age of $\mathrm{HH}$ head & $\begin{array}{c}-1.540^{* * *} \\
{[0.403]}\end{array}$ & Main light source is electricity & $\begin{array}{l}-3.007 \\
{[3.759]}\end{array}$ & Presence of business in EA & $\begin{array}{l}2.937^{* *} \\
{[1.460]}\end{array}$ \\
\hline Observations & 576 & & 576 & & 576 \\
\hline
\end{tabular}

Note: Heteroskedasticity robust standard errors in brackets. ${ }^{*} \mathrm{p}<0.1{ }^{* *} \mathrm{p}<0.05,{ }^{* * *} \mathrm{p}<0.01$.

$\mathrm{HH}$ stands for household; EA stands for Enumeration Area.

All regressions are weighted by the size of the EA and include eight sublocation fixed effects.

The first two columns are results from one regression of luminosity on the reported variables in the column.

In the third column, each cell reports results from a separate regression as all these variables are extremely highly correlated. 
Appendix Table A3A: Rents: Alternative Specifications (Dependent Variable is Log Rent)

\begin{tabular}{|c|c|c|c|c|c|c|c|c|c|}
\hline & $(1)$ & (2) & (3) & (4) & (5) & (6) & (7) & (8) & (9) \\
\hline Landlord-Chief (LC) tribe match & $\begin{array}{c}0.065^{* * *} \\
{[0.020]}\end{array}$ & $\begin{array}{c}0.051^{* * *} \\
{[0.019]}\end{array}$ & $\begin{array}{c}0.071^{* * *} \\
{[0.021]}\end{array}$ & $\begin{array}{l}0.053^{* *} \\
{[0.022]}\end{array}$ & $\begin{array}{c}0.076^{* * *} \\
{[0.027]}\end{array}$ & $\begin{array}{c}0.056^{*} \\
{[0.029]}\end{array}$ & $\begin{array}{l}0.053^{* *} \\
{[0.022]}\end{array}$ & $\begin{array}{c}0.032 \\
{[0.025]}\end{array}$ & $\begin{array}{c}0.032 \\
{[0.024]}\end{array}$ \\
\hline Tenant-Chief (TC) tribe match & $\begin{array}{c}-0.073^{* * *} \\
{[0.019]}\end{array}$ & $\begin{array}{c}-0.066^{* * *} \\
{[0.018]}\end{array}$ & $\begin{array}{c}-0.081^{* * *} \\
{[0.021]}\end{array}$ & $\begin{array}{c}-0.064^{* * *} \\
{[0.021]}\end{array}$ & $\begin{array}{c}-0.075^{* * *} \\
{[0.028]}\end{array}$ & $\begin{array}{c}-0.060^{* *} \\
{[0.028]}\end{array}$ & $\begin{array}{c}-0.072^{* * *} \\
{[0.026]}\end{array}$ & $\begin{array}{c}-0.062^{* *} \\
{[0.026]}\end{array}$ & $\begin{array}{c}-0.062^{* *} \\
{[0.026]}\end{array}$ \\
\hline Landlord-Tenant (LT) tribe match & $\begin{array}{c}-0.008 \\
{[0.015]}\end{array}$ & $\begin{array}{c}0.012 \\
{[0.015]}\end{array}$ & $\begin{array}{c}0.006 \\
{[0.015]}\end{array}$ & $\begin{array}{c}0.020 \\
{[0.016]}\end{array}$ & $\begin{array}{c}0.012 \\
{[0.020]}\end{array}$ & $\begin{array}{c}0.024 \\
{[0.021]}\end{array}$ & $\begin{array}{c}-0.004 \\
{[0.018]}\end{array}$ & $\begin{array}{c}0.012 \\
{[0.020]}\end{array}$ & \\
\hline F Stat for $\mathrm{LC}+\mathrm{TC}=0$ & 0.075 & 0.300 & 0.121 & 0.146 & 0.000 & 0.010 & 0.248 & 0.548 & 0.608 \\
\hline P-Value & 0.784 & 0.584 & 0.728 & 0.702 & 0.996 & 0.922 & 0.619 & 0.460 & 0.436 \\
\hline Dependent Variable Mean & 7.255 & 7.306 & 7.255 & 7.306 & 7.232 & 7.290 & 7.248 & 7.302 & 7.302 \\
\hline Village FE & $\mathrm{X}$ & $\mathrm{X}$ & $x$ & $\mathrm{X}$ & $\mathrm{X}$ & $X$ & $x$ & $\mathrm{X}$ & $X$ \\
\hline All Controls & & $\mathrm{X}$ & & $x$ & & $X$ & & $x$ & $\mathrm{X}$ \\
\hline No Weights & $X$ & $X$ & & & & & & & \\
\hline No Clustering & & & $x$ & $x$ & & & & & \\
\hline Trim Top Percentile & & & & & $\mathrm{X}$ & $X$ & & & \\
\hline Drop Laini Saba & & & & & & & $x$ & $X$ & $X$ \\
\hline R-squared & .39 & 319 & .4 & .319 & .36 & .281 & .409 & .329 & .329 \\
\hline Observations & 14311 & 11577 & 14311 & 11577 & 14174 & 11498 & 13516 & 10885 & 10885 \\
\hline
\end{tabular}

Note: Standard errors clustered at the location-tenant tribe-landlord tribe level (reported in brackets). ${ }^{*} p<0.1,{ }^{* *} p<0.05,{ }^{* * *} p<0.01$.

The standard errors reported in columns (3) and (4) are heteroskedasticity robust standard errors. 
Appendix Table A3B: More On Rents

\begin{tabular}{|c|c|c|c|c|c|c|c|c|}
\hline & \multicolumn{2}{|c|}{ Rent } & \multicolumn{2}{|c|}{ Log Listing Rent } & \multicolumn{2}{|c|}{ Change in Rent } & \multicolumn{2}{|c|}{ Pay Rent } \\
\hline & (1) & (2) & (3) & (4) & (5) & (6) & (7) & (8) \\
\hline Landlord-Chief (LC) tribe match & $\begin{array}{l}\text { 107.123* } \\
\text { [56.177] }\end{array}$ & $\begin{array}{l}84.717^{*} \\
\text { [43.730] }\end{array}$ & $\begin{array}{c}0.089^{* * *} \\
{[0.023]}\end{array}$ & $\begin{array}{c}0.078^{* * *} \\
{[0.025]}\end{array}$ & $\begin{array}{c}24.226 \\
{[18.622]}\end{array}$ & $\begin{array}{c}19.093 \\
{[19.738]}\end{array}$ & & \\
\hline Tenant-Chief (TC) tribe match & $\begin{array}{c}-225.621^{* * *} \\
{[62.703]}\end{array}$ & $\begin{array}{c}-130.421^{* * *} \\
{[46.202]}\end{array}$ & $\begin{array}{c}-0.108^{* * *} \\
{[0.023]}\end{array}$ & $\begin{array}{c}-0.075^{* * *} \\
{[0.021]}\end{array}$ & $\begin{array}{c}10.595 \\
{[21.205]}\end{array}$ & $\begin{array}{c}19.565 \\
{[23.125]}\end{array}$ & $\begin{array}{l}-0.033 \\
{[0.024]}\end{array}$ & $\begin{array}{l}-0.031 \\
{[0.023]}\end{array}$ \\
\hline Landlord-Tenant (LT) tribe match & $\begin{array}{l}-10.715 \\
{[52.385]}\end{array}$ & $\begin{array}{c}15.272 \\
{[48.269]}\end{array}$ & $\begin{array}{c}0.012 \\
{[0.019]}\end{array}$ & $\begin{array}{c}0.024 \\
{[0.020]}\end{array}$ & $\begin{array}{c}7.762 \\
{[19.561]}\end{array}$ & $\begin{array}{c}1.118 \\
{[23.044]}\end{array}$ & & \\
\hline F Stat $\mathrm{LC}+\mathrm{HC}=0$ & 1.812 & 0.497 & 0.376 & 0.007 & 1.721 & 1.744 & & \\
\hline P-Value & 0.180 & 0.482 & 0.540 & 0.936 & 0.191 & 0.188 & & \\
\hline Dep Var Mean & 1672.439 & 1631.617 & 7.158 & 7.206 & 126.206 & 126.385 & 0.924 & 0.923 \\
\hline Village FE & $x$ & $x$ & $X$ & $X$ & $x$ & $X$ & $x$ & $X$ \\
\hline All Controls & & $x$ & & $\mathrm{X}$ & & $\mathrm{X}$ & & $\mathrm{X}$ \\
\hline R-squared & .476 & .425 & .485 & .39 & .013 & .024 & .149 & .166 \\
\hline Observations & 11101 & 9041 & 11101 & 9041 & 10538 & 8545 & 16380 & 13341 \\
\hline
\end{tabular}

Note: Standard errors clustered at the location-tenant tribe-landlord tribe level (reported in brackets). ${ }^{*} \mathrm{p}<0.1,{ }^{* *} \mathrm{p}<0.05,{ }^{* * *} \mathrm{p}<0.01$. All controls refers to village fixed effects, housing, amenities and other controls.

The change in rent (columns (5)-(6)) is the difference between the census and resident survey rents. These regressions are not weighted.

The pay rent dummy (columns (7)-(8)) indicates whether the resident paid any rent (those that do not pay do not have landlords).

The standard errors in the last column are clustered at the location-resident tribe level. 
Appendix Table A4: Rents and Luminosity, Robustness to Controls

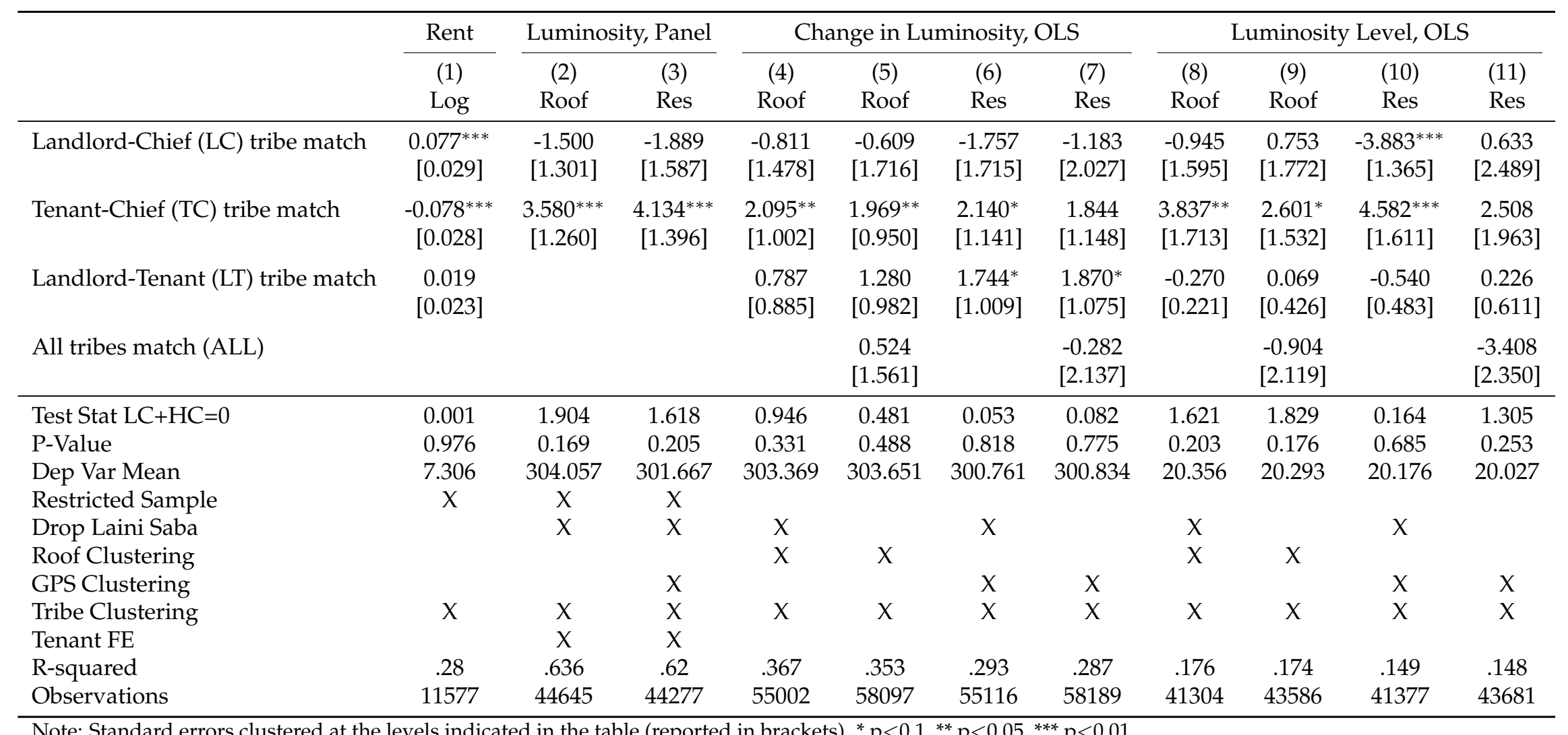

Note: Standard errors clustered at the levels indicated in the table (reported in brackets). ${ }^{*} \mathrm{p}<0.1,{ }^{* *} \mathrm{p}<0.05,{ }^{* * *} \mathrm{p}<0.01$.

Columns (1)-(3) show robustness to sample. We restrict the sample to the subset where controls are available.

All specifications control for only village fixed effects, GPS coordinates and period fixed effects (for luminosity).

The luminosity data is extracted from satellite images of Kibera for four periods, July 2009, January 2011, December 2011, August 2012.

All results for luminosity use the trimmed luminosity data (top and bottom one percentiles removed).

Roof represents the roof level measure of luminosity and Res represents the resident measure. See text for details on how these are computed.

The panel regressions cannot be clustered at the roof level since roofs cannot be matched across periods (or pictures). 
Appendix Table A5: Heterogeneity along Measures of Ethnic Diversity and Youth Unemployment

Dependent Variable is Log Rent

\begin{tabular}{|c|c|c|c|c|c|}
\hline & $\begin{array}{c}(1) \\
\text { High Unemployment }\end{array}$ & $\begin{array}{c}(2) \\
\text { High Unemployment }\end{array}$ & $\begin{array}{c}(3) \\
\text { Diversity, EA Level }\end{array}$ & $\begin{array}{c}(4) \\
\text { Diversity, Zone Level }\end{array}$ & $\begin{array}{c}(5) \\
\text { Diversity, Village Level }\end{array}$ \\
\hline LC Match*Variable & $\begin{array}{c}-0.063^{* * *} \\
{[0.021]}\end{array}$ & $\begin{array}{c}-0.074^{* * *} \\
{[0.022]}\end{array}$ & $\begin{array}{l}-0.011 \\
{[0.043]}\end{array}$ & $\begin{array}{c}-0.159^{* * *} \\
{[0.050]}\end{array}$ & $\begin{array}{c}-0.184^{* * *} \\
{[0.040]}\end{array}$ \\
\hline TC Match*Variable & $\begin{array}{l}-0.005 \\
{[0.031]}\end{array}$ & $\begin{array}{c}0.005 \\
{[0.028]}\end{array}$ & $\begin{array}{l}-0.064 \\
{[0.052]}\end{array}$ & $\begin{array}{l}-0.070 \\
{[0.071]}\end{array}$ & $\begin{array}{l}-0.068 \\
{[0.058]}\end{array}$ \\
\hline LT Match*Variable & $\begin{array}{c}0.027 \\
{[0.019]}\end{array}$ & $\begin{array}{c}0.016 \\
{[0.018]}\end{array}$ & $\begin{array}{l}-0.012 \\
{[0.041]}\end{array}$ & $\begin{array}{c}0.007 \\
{[0.040]}\end{array}$ & $\begin{array}{c}0.017 \\
{[0.042]}\end{array}$ \\
\hline Landlord-Chief (LC) tribe match & $\begin{array}{c}0.089^{* * *} \\
{[0.031]}\end{array}$ & $\begin{array}{l}0.080^{* *} \\
{[0.040]}\end{array}$ & $\begin{array}{c}0.037 \\
{[0.053]}\end{array}$ & $\begin{array}{l}0.127^{* *} \\
{[0.052]}\end{array}$ & $\begin{array}{c}0.144^{* * *} \\
{[0.049]}\end{array}$ \\
\hline Tenant-Chief (TC) tribe match & $\begin{array}{l}-0.062^{*} \\
{[0.033]}\end{array}$ & $\begin{array}{l}-0.084^{*} \\
{[0.046]}\end{array}$ & $\begin{array}{l}-0.040 \\
{[0.059]}\end{array}$ & $\begin{array}{l}-0.048 \\
{[0.062]}\end{array}$ & $\begin{array}{l}-0.035 \\
{[0.068]}\end{array}$ \\
\hline Landlord-Tenant (LT) tribe match & $\begin{array}{c}0.007 \\
{[0.024]}\end{array}$ & $\begin{array}{l}0.081^{* *} \\
{[0.035]}\end{array}$ & $\begin{array}{c}0.103^{* * *} \\
{[0.036]}\end{array}$ & $\begin{array}{l}0.081^{* *} \\
{[0.038]}\end{array}$ & $\begin{array}{c}0.083^{* *} \\
{[0.040]}\end{array}$ \\
\hline $\begin{array}{l}\text { Dependent Variable Mean } \\
\text { Education Interac } \\
\text { Wealth Interac } \\
\text { Poverty Interac } \\
\text { All Controls } \\
\text { R-squared } \\
\text { Observations }\end{array}$ & $\begin{array}{c}X \\
.32 \\
11577\end{array}$ & $\begin{array}{l}7.306 \\
X \\
X \\
X \\
X \\
.32 \\
11577\end{array}$ & $\begin{array}{l}7.306 \\
X \\
X \\
X \\
X \\
.321 \\
11577\end{array}$ & $\begin{array}{l}7.306 \\
X \\
X \\
X \\
X \\
.326 \\
11577\end{array}$ & $\begin{array}{l}7.306 \\
X \\
X \\
X \\
X \\
.325 \\
11577\end{array}$ \\
\hline
\end{tabular}

Note: Standard errors clustered at the location-tenant tribe-landlord tribe level (reported in brackets). ${ }^{*} \mathrm{p}<0.1,{ }^{* *} \mathrm{p}<0.05,{ }^{* * *} \mathrm{p}<0.01$

All controls refers to village fixed effects, housing, amenities and other controls.

Column titles refer to the variable that is interacted with the match dummies.

The diversity indices are based on a Hirschman-Herfindahl index, as defined in the paper.

The interactions in all columns are with dummy variables for the relevant variable being greater than the median in the sample.

The Education, Wealth and Poverty Interac controls include levels of the variable and its interactions with all the match variables.

Wealth is an EA level principal components index using 2009 census data.

The poverty rate (less than 2 dollars a day) is at the EA level and estimated using the methodology in Elbers, Lanjouw and Lanjouw (2003). 
Appendix Table A6: RD Specification, Balance Checks

\begin{tabular}{|c|c|c|c|}
\hline & CCT & $2 \times \mathrm{CCT}$ & Polynomial \\
\hline \multirow[t]{2}{*}{ Roof size } & 1.522 & -20.412 & 38.01 \\
\hline & [67.438] & [64.162] & [50.548] \\
\hline \multirow{2}{*}{ How many HHs in this structure? } & -.422 & -.87 & -.741 \\
\hline & [1.073] & {$[.824]$} & {$[.759]$} \\
\hline \multirow[t]{2}{*}{ EA listed as informal (slum) } & -.011 & $-.012^{* *}$ & -.007 \\
\hline & {$[.009]$} & {$[.005]$} & .008 \\
\hline \multirow[t]{2}{*}{ Walls are made of mud/wood } & -.04 & -.002 & -.008 \\
\hline & [.091] & {$[.072]$} & {$[.062]$} \\
\hline \multirow[t]{2}{*}{ Floor is made of earth } & $-.134^{* *}$ & -.057 & -.036 \\
\hline & {$[.055]$} & [.045] & {$[.041]$} \\
\hline \multirow{2}{*}{ Main water source water vendor } & $.341^{* * *}$ & $.26^{* * * *}$ & .115 \\
\hline & [.1] & {$[.081]$} & {$[.079]$} \\
\hline \multirow{2}{*}{ Main waste uncovered pit } & -.026 & .011 & -.036 \\
\hline & [.101] & {$[.08]$} & {$[.064]$} \\
\hline \multirow[t]{2}{*}{ Main cooking fuel is paraffin } & .053 & .022 & .035 \\
\hline & {$[.055]$} & {$[.045]$} & {$[.036]$} \\
\hline \multirow[t]{2}{*}{ Main light source is electricity } & .02 & -.004 & -.021 \\
\hline & {$[.045]$} & {$[.032]$} & {$[.033]$} \\
\hline \multirow[t]{2}{*}{ Age of household head } & -.062 & -.286 & .054 \\
\hline & {$[.58]$} & [.462] & {$[.372]$} \\
\hline \multirow[t]{2}{*}{ Household head works for pay } & -.06 & $-.049^{*}$ & $-.062^{* *}$ \\
\hline & {$[.037]$} & {$[.029]$} & {$[.027]$} \\
\hline \multirow[t]{2}{*}{ Household head owns a business } & .045 & $.048^{*}$ & $.044^{*}$ \\
\hline & {$[.034]$} & {$[.025]$} & {$[.023]$} \\
\hline \multirow[t]{2}{*}{ Head works for private sector } & .033 & .031 & .039 \\
\hline & {$[.052]$} & {$[.042]$} & {$[.038]$} \\
\hline \multirow[t]{2}{*}{ Household head has no education } & -.012 & -.009 & -.008 \\
\hline & {$[.008]$} & {$[.006]$} & {$[.006]$} \\
\hline \multirow[t]{2}{*}{ Head has secondary education } & -.02 & -.03 & -.021 \\
\hline & {$[.025]$} & {$[.019]$} & {$[.018]$} \\
\hline \multirow[t]{2}{*}{ Head, years of education } & .262 & .066 & .117 \\
\hline & {$[.257]$} & {$[.208]$} & {$[.174]$} \\
\hline \multirow[t]{2}{*}{ Head, hours worked in 7 days } & $-5.224^{* *}$ & $-4.709^{* *}$ & $-3.636^{* *}$ \\
\hline & {$[2.536]$} & [1.965] & [1.664] \\
\hline \multirow[t]{2}{*}{ TV } & .029 & .001 & .009 \\
\hline & {$[.029]$} & {$[.022]$} & {$[.022]$} \\
\hline \multirow[t]{2}{*}{ Radio } & $.046^{*}$ & .026 & .012 \\
\hline & {$[.024]$} & {$[.018]$} & {$[.017]$} \\
\hline \multirow[t]{2}{*}{ Mobile phone } & .026 & .028 & 0 \\
\hline & {$[.023]$} & {$[.018]$} & {$[.016]$} \\
\hline \multirow[t]{2}{*}{ Bicycle } & .001 & -.004 & -.004 \\
\hline & {$[.014]$} & {$[.011]$} & {$[.009]$} \\
\hline \multirow[t]{2}{*}{ Wealth index } & $.604^{*}$ & .266 & .175 \\
\hline & {$[.335]$} & {$[.266]$} & {$[.239]$} \\
\hline \multirow[t]{2}{*}{ Poverty } & -.013 & .009 & -.001 \\
\hline & {$[.025]$} & {$[.021]$} & {$[.018]$} \\
\hline
\end{tabular}

Note: Standard errors are clustered at the EA level (reported in brackets). ${ }^{*} \mathrm{p}<0.1,{ }^{* *} \mathrm{p}<0.05,{ }^{* * *} \mathrm{p}<0.01$. Each cell is from a separate regression with the same RD specification as in Table 6. CCT indicates a bandwidth of 200 meters. $2 \times$ CCT indicates a bandwidth of 400 meters. The first coefficient on roof size is reported multiplied by 1000. 
Appendix Figure A1: Household Sampling Strategy

2012 Census: 31,765 Households

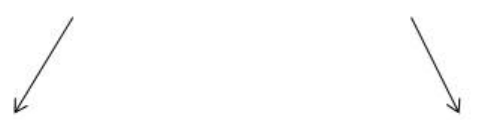

Households With

Phones: 20,712

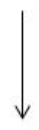

Households

Households Not

Reached: 16,314 Reached: 4,398

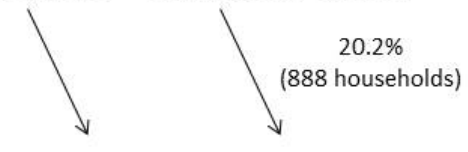

\section{Households Without} Phones: 11,053

Household Survey Sample Targeted: 18,797 Households Household Survey Sample Reached: 18,254 Households

$$
\begin{array}{|l}
10 \% \text { missing } \\
\text { household or } \\
\text { landlord tribe }
\end{array}
$$

Analysis Sample: 16,262 Households of which 14,311 Households pay rent 
Appendix Figure A2: Old and New Roofs in Kibera

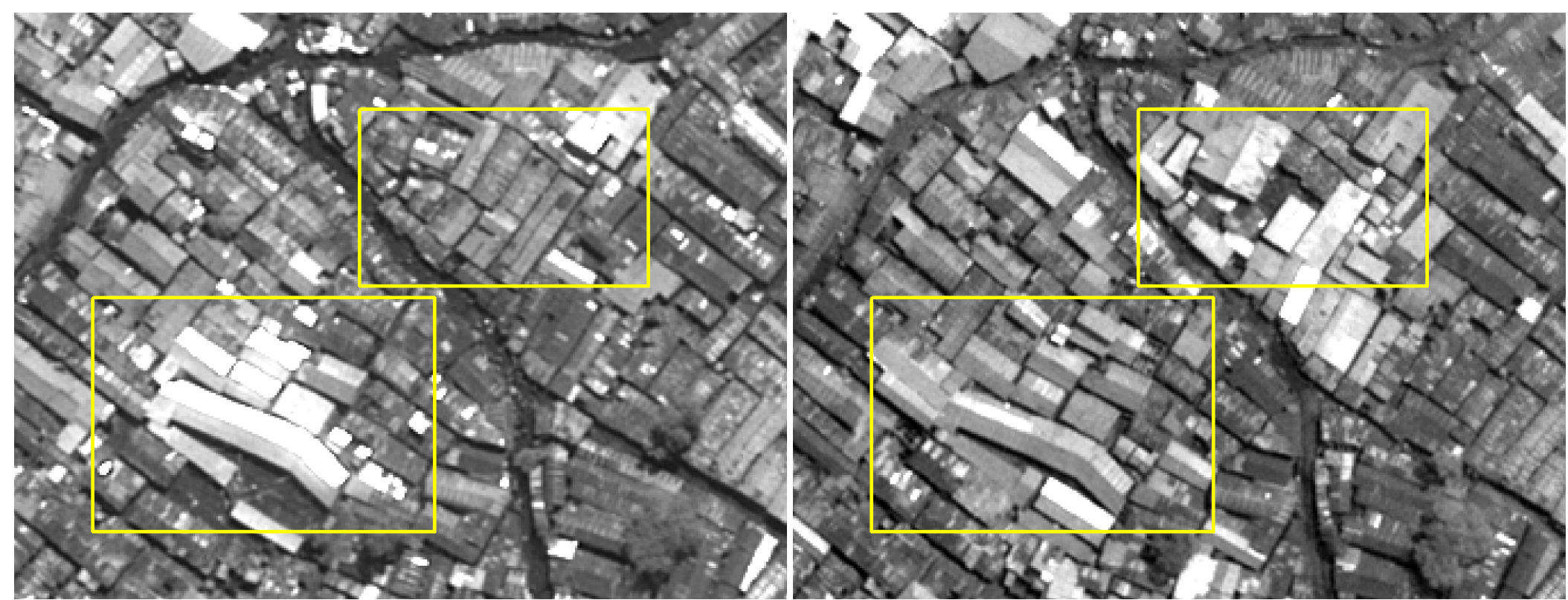

Note: Both pictures are taken over the same area of the slum with the same resolution ( 0.5 meters panchromatic).

The picture in the left panel was taken in July 2009 and that in the right panel in August 2012.

The yellow rectangles highlight clusters of roofs that markedly evolved over the period.

Roofs highlighted in the bottom rectangle degraded while roofs within the top rectangle were upgraded in the same timeframe.

The picture area is approximately 175 meters long and 140 meters wide. 
Appendix Figure A3: Roof Luminosity and Household Consumption Across Kibera
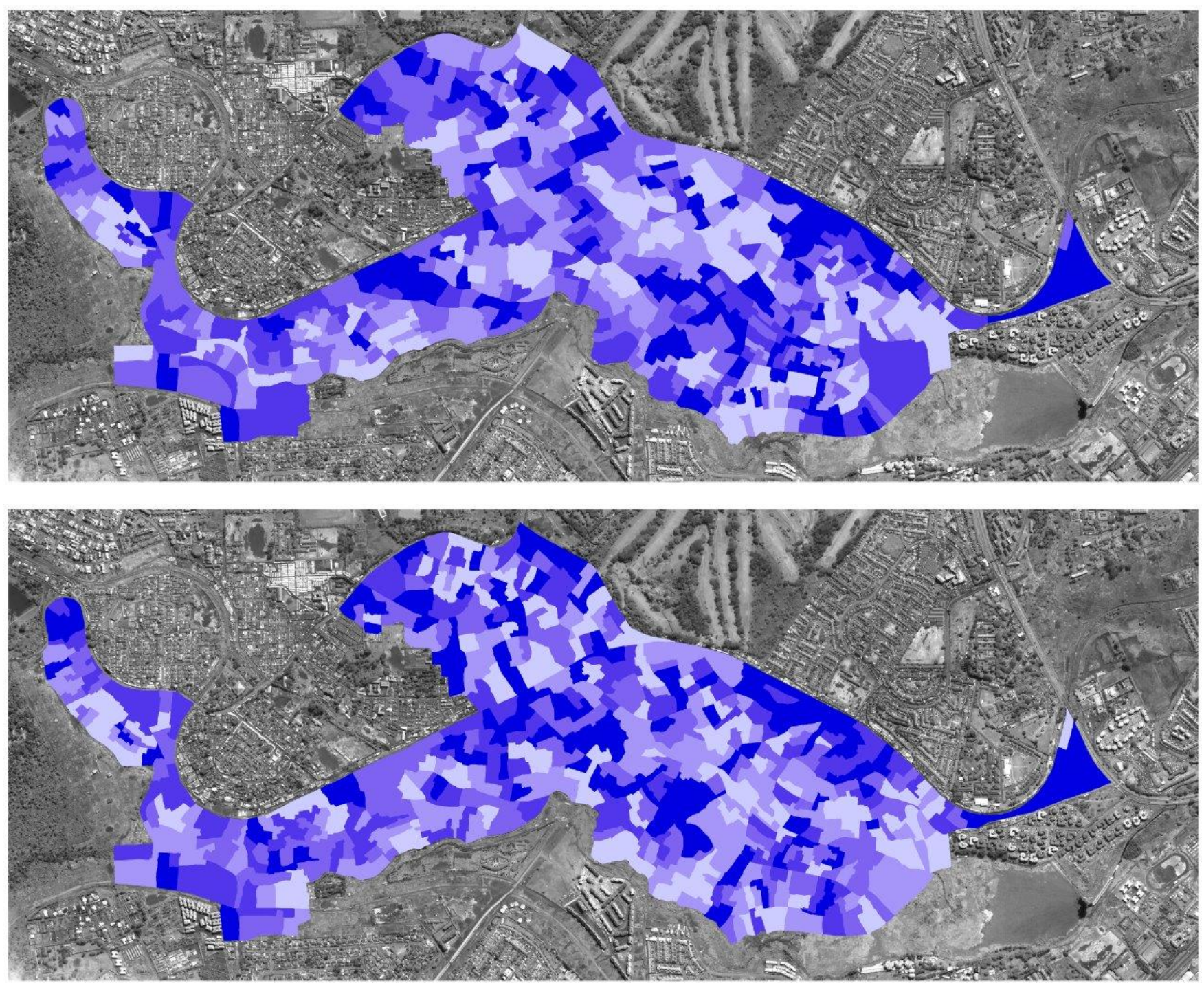

Note: The top panel displays mean luminosity by EA and the bottom mean (estimated) household consumption by EA.

The data used are residualized values after accounting for the sublocation fixed effects in a regression framework.

The blue color scale is divided into the 5 quintiles in the data. The picture only includes the 546 informal EAs in the 2009 census. 